\title{
A evolução da prova entre o direito civil e o direito processual civil
}

\author{
The evolution of proof between private law and procedural law
}

\author{
Gustavo Tepedino* \\ Francisco de Assis Viégas ${ }^{* *}$
}

\section{Resumo}

\begin{abstract}
A disciplina da prova no Código Civil revela-se controversa na doutrina. No ordenamento complexo e unitário, devem ser rechaçadas as críticas fundadas em concepção que entrevê as disciplinas jurídicas em compartimentos estanques, cada qual regulamentada pela respectiva lei ou código. A disciplina da prova deverá ser compreendida no contexto de interação, em cada caso concreto, entre as diversas fontes normativas. De outra parte, a opção legislativa pela regulamentação autônoma da prova no Código Civil encontra resistência em virtude da relação, nem sempre bem compreendida, entre forma e prova do negócio jurídico, o que se evidencia na controversa categoria da chamada forma ad probationem. A adequada compreensão da disciplina da prova adquire importância sensível diante das novas tecnologias, sobretudo para que se possa valorar, na legalidade constitucional, as denominadas provas eletrônicas. $O$ artigo se propõe à análise da regulamentação da prova, notadamente no Código Civil e no Código de Processo Civil, com o escopo de harmonizar as normativas e estabelecer algumas premissas para avaliar o merecimento de tutela das provas na sociedade tecnológica.
\end{abstract}

Palavras-chave: Prova. Código Civil. CPC/2015. Forma ad probationem. Prova eletrônica.

\section{Abstract}

The legal regulation of proof in the Civil Code is controversial among legal scholars. At the complex and unitary system, the criticisms based on the conception that takes law subjects as impenetrable compartments, each one regulated by a specific law or code, must be refused. The legal regulation of proof must be comprehended in the context of interaction between legal sources in each case. Furthermore, the political choice for an autonomous regulation of proof in the Civil Code faces resistance in the relation, often misunderstood, between form and proof of contracts, issue that becomes unequivocal when confronted with the so-called "form ad probationem". The proper comprehension of the legal regulation of proof acquires special importance with the arising of emerging technologies, mainly to make it possible to review, based on constitutional legality, the electronic proof. The article aims to analyze the legal regulation of proof, especially on the Civil Code and in the CPC/2015, with the purpose of harmonizing the legal sources and stablishing some propositions to evaluate the lawfulness of proofs at the technological society.

Keywords: Proof. Civil Code. CPC/2015. Form ad probationem. Eletronic proof.

\section{Introdução}

A funcionalização das normas e institutos do direito civil à axiologia constitucional, com a consequente remodelação da dogmática da teoria geral do direito, situa-se no contexto mais amplo de harmonização

\footnotetext{
* Professor Titular de Direito Civil da Faculdade de Direito da Universidade do Estado do Rio de Janeiro - UERJ. Doutor em Direito Civil pela Universidade de Camerino (Itália) e Livre-Docente pela Faculdade de Direito da UERJ. Presidente do Instituto Brasileiro de Direito Civil - IBDCivil. Advogado, consultor e parecerista em Direito Privado. Rio de Janeiro - RJ - Brasil. E-mail: gt@tepedino.adv.br.

** Mestrando em Direito Civil pela Universidade do Estado do Rio de Janeiro - UERJ. Bacharel em Direito pela Universidade do Estado do Rio de Janeiro - UERJ (2015). Bolsista de iniciação científica do CNPq de 2013 a 2016, sob orientação do Professor Gustavo Tepedino. Rio de Janeiro -RJ - Brasil. E-mail: fav@tepedino.adv.br.
} 
das fontes normativas a partir da precedência hierárquica da Constituição. Se o direito é realidade cultural, o que parece hoje fora de dúvida, é a pessoa humana, na experiência brasileira, que se encontra no ápice do ordenamento, devendo a ela se submeter o legislador ordinário, o intérprete e o magistrado. Tal o único método capaz de, superando o positivismo dogmático e o realismo sociológico, garantir estabilidade ao direito, como ordenamento unitário de uma sociedade multifacetada e em contínua mutação. ${ }^{1}$

O conceito de ordenamento pressupõe o conjunto de normas destinadas a ordenar a sociedade segundo determinado modo de vida historicamente determinado (PERLINGIERI, 2002, p. 2). Por ser o ordenamento jurídico composto por uma pluralidade de fontes normativas, apresenta-se necessariamente como sistema heterogêneo e aberto: daí a sua complexidade que, por sua vez, só alcançará a unidade caso seja assegurada a centralidade da Constituição, que contém a tábua de valores que caracterizam a identidade cultural da sociedade. ${ }^{2}$ Tal pluralidade de fontes normativas, contudo, não pode significar perda do fundamento unitário característico da própria noção de ordenamento, devendo sua harmonização se operar de acordo com a Constituição, que o recompõe continuamente, conferindo-lhe, assim, a natureza de sistema. Ou seja, a pluralidade de núcleos legislativos deve conviver harmonicamente com a noção de unidade do ordenamento. Do ponto de vista da teoria da interpretação, mostra-se imprescindível que a pluralidade de fontes normativas não acarrete a ruptura do sistema, disperso em lógicas setoriais, em detrimento da unidade essencial ao próprio conceito de ordenamento (TEPEDINO, 2015, p. 6-7).

O desafio do jurista de hoje encontra-se em lidar com a complexidade dos núcleos normativos que caracterizam o sistema, composto pela Constituição, leis gerais, especiais, tratados internacionais, promulgados em experiências culturais e momentos históricos diferenciados. Diálogo de fontes, portanto, há de ser perseguido, sem que tal formulação dialética se deixe transformar, arbitrariamente, em monólogo, em que se privilegiasse arbitrariamente o Código Civil ou qualquer outro núcleo normativo. ${ }^{3}$

A ampla controvérsia atinente à disciplina da prova bem simboliza a dificuldade de parte da doutrina em lidar com a pluralidade de fontes normativas. ${ }^{4} \mathrm{~A}$ opção levada a cabo pelo legislador ao instituir, no Código Civil, título dedicado à prova (artigos 212 a 232), ${ }^{5}$ gerou críticas, sendo possível afirmar que ainda hoje constitui objeto de disputas quanto à natureza - processual ou material - da prova, havendo quem considere verdadeiro "retrocesso científico" a regulamentação da prova no Código Civil (CINTRA; GRINOVER; DINAMARCO, 2013, p. 385). ${ }^{6}$ A resistência deve-se, em larga medida, à concepção das disciplinas jurídicas como compartimentos estanques, fundada na crença oitocentista dos monumentos legislativos completos e autossuficientes.

Segundo leciona Pietro Perlingieri (2005, p. 192), "l'ordinamento, tuttavia, non si esaurisce nella complessità della sua genesi legislativa e normativa; la complessità dell'ordinamento è data dall'impatto con il sistema socio-culturale di appartenenza, che non è aspetto fattuale privo di capacità condizionante. Ma à aspetto strutturale conformativo e adeguatore e, quindi, realmente contenutistico dello ius. Societas è cultura, e questa vive nel momento applicativo, creativo dell'ordinamento del caso concreto, attraverso anche la cultura degli operatori: giudici, avvocati, notai, funzionari. In tal modo l'esperienza arricchisce la norma, la plasma e la rende effetiva".

Conforme destacado em outra sede, "a complexidade do ordenamento, em última análise, não decorre apenas de sua gênese - análise estrutural entre direito interno e externo e distinção cronológica e hierárquica da produção normativa - mas da tensão dialética representada por sua inserção na realidade social. A experiência vivida forja a norma, e a cultura - como complexo de experiências econômica, religiosa, política, tecnológica - condiciona internamente o sistema jurídico e, conseguintemente, a teoria da interpretação, que assume necessariamente feição procedimental e dinâmica na formulação, pelo magistrado, da norma interpretada, ou do ordenamento do caso concreto, promulgado em cada sentença". (TEPEDINO, 2016, p. 22).

Sobre o tema, em perspectiva distinta, v. Marques (2016, p. 135-154). Cfr., ainda, a formulação de Erik Jayme (1955, p. 33 e ss.).

Washington de Barros Monteiro (2007, p. 294) observa a "imensa dificuldade para a perfeita localização de sua teoria, que se situa nas confrontações do direito público e do direito privado. Deparam-se realmente numerosos dispositivos sobre tal matéria, tanto no direito civil como no comercial e no judiciário. Essa dispersão embaraça sobremaneira a sistematização do direito probatório". José Carlos Barbosa Moreira (2005, p. 97-99) anota que a legislação brasileira sobre prova fica "dividida entre dois códigos [...]. Destarte, nosso direito probatório de hoje é o resultado da superposição de dois retículos normativos, com pontos e espaços que nem sempre coincidem".

Como se sabe, o Código Civil de 1916 tratava, nos artigos 129 a 144, da "forma dos atos jurídicos e da sua prova".

6 Segundo os autores, "embora vários temas sobre a prova venham às vezes tratados na lei civil, trata-se de autentica matéria processual - porque falar em provas significa pensar na formação do convencimento do juiz, no processo. Mas o novo Código Civil invadiu radicalmente essa área, com disposições de caráter nitidamente processual, o que constitui retrocesso científico" (CINTRA; GRINOVER; DINAMARCO, 2013, p. 385). 
Nada obstante, a disciplina da prova inserida no Código Civil convive com a normativa presente no Código de Processo Civil de 2015, que dedica um capítulo às provas, nos termos dos artigos 369 a 484. Torna-se necessário, por isso mesmo, harmonizar a normativa vigente a partir da função da prova - sua finalidade e razão de ser -, superando assim controvérsias baseadas exclusivamente na análise estrutural dos dispositivos.

De acordo com conceituada definição, a prova consiste no "conjunto dos meios empregados para demonstrar, legalmente, a existência de um ato jurídico". ${ }^{7}$ Daí desenvolver-se a teoria da prova em "zona fronteiriça”" entre o direito material e o processual (BEVILAQUA, 1908, p. 321-323; PEREIRA, 2016a, p. 493). Procura-se, com isso, delimitar os respectivos campos regulados pela lei civil e pela lei processual, incorrendo por vezes no equívoco de fundamentar o raciocínio em modelos binários incompatíveis com a perspectiva unitária e sistemática do ordenamento. ${ }^{8}$

Afirma-se, nessa direção, que ao direito civil caberia "determinar os requisitos para a validade da emissão volitiva, bem como pronunciar-se a respeito do valor de certo meio de prova do negócio jurídico", enquanto à lei processual "fica reservado, por exemplo, a atribuição de disciplinar o modo através do qual os advogados dos litigantes deverão se utilizar, bem como o tempo processual oportuno, para a demonstração da existência e validade do negócio jurídico" (OLIVEIRA, 2013, p. 500). ${ }^{9}$ Em matiz semelhante, afirma-se que "ao direito civil cabe realizar a determinação das provas, indicar seu valor jurídico e suas condições de admissibilidade" e "ao direito processual, são reservadas as atribuições de fixar o modo de constituir a prova e de produzi-la em juízo". ${ }^{10}$ (GAMA, 2007, p.590).

Apesar da grande importância atribuída pela doutrina à definição da natureza das normas sobre a prova, mediante a indicação de campos específicos em que prevaleceria a disciplina material ou processual, verifica-se que não são raras as oportunidades em que o Código Civil e o Código de Processo Civil veiculam normas com função idêntica, frustrando as tentativas de segmentar, em mirada abstrata e generalizante, os domínios da prova no direito civil e no direito processual. Ilustrativamente, basta confrontar alguns dispositivos do Código Civil com outros do Código de Processo Civil: o artigo 214 do Código Civil prevê que "a confissão é irrevogável, mas pode ser anulada se decorreu de erro de fato ou de coação", em redação idêntica à do artigo 393 do CPC;11 o artigo 219, caput, do Código Civil, por sua vez, estatui que "as declarações constantes de documentos assinados presumem-se verdadeiras em relação aos signatários", enquanto o artigo 408, caput, do CPC, estabelece que "as declarações constantes do

O conceito é amplamente adotado pela doutrina clássica. V. Serpa Lopes, (1989, p. 381). José Carlos Barbosa Moreira (2005, p. 105), discorrendo sobre a função da prova no processo, afirma que "as provas constituem as pontes através das quais os fatos passam para chegar, primeiro, aos sentidos, depois à mente do juiz (nihil est intellectu quod prius non fuerit in sensu)".

8 Conforme observa Pietro Perlingieri (2002, p. 77-78), "a unidade interna não é um dado contingente, mas, ao contrário, é essencial ao ordenamento, sendo representado pelo complexo de relações e de ligações efetivas e potenciais entre as normas singulares e entre os institutos". Afirma o autor, ainda, que "um ordenamento a-sistemático, isto é, feito de normas que não exprimem relações internas, não encontrou até hoje uma verificação histórica. [...]. Se o critério de fundação do sistema privilegia o conteúdo sobre a forma (contenutistico), sendo, portanto, fruto de elaboração, das correlações entre um e outro instituto, o sentido do sistema se deduz não no esplêndido isolamento da relação do intérprete com o conteúdo de cada norma, mas sempre confrontando cada norma com todas as outras, verificando a sua coerência constitucional".

9 Clovis Bevilaqua (1908, p. 323) afirma que "cabe ao direito civil determinar as provas dos atos jurídicos, indicar-lhes o valor legal e as condições de sua admissibilidade, porque, nesses diversos momentos, as provas fazem corpo com a forma dos atos, orientam e limitas a atividade das pessoas na ordem jurídica. Ao direito processual pertence estabelecer os modos de constitui-las e de produzi-las em juízo". As dificuldades presentes em tais proposições revelam-se presentes até mesmo ao se analisar a divisão proposta por outros autores, como se percebe da descrição de José Carlos Barbosa Moreira (2005, p. 98) sobre a lição clássica da doutrina, segundo a qual ao direito substantivo caberia disciplinar questões relativas "à essência das provas, à sua admissibilidade, aos seus efeitos, às pessoas que devem ministra-las".

10 Seguindo no raciocínio, afirma o autor: "enquanto o Direito Civil define os meios de prova, enuncia os lineamentos do regime a que deve se submeter a comprovação do fato jurídico (em sentido amplo) - em especial a declaração de vontade -, ao direito processual incumbe estabelecer a técnica de apresentação e valoração da prova em juízo. Em resumo: a) nos casos em que houver litígio levado ao conhecimento do Poder Judiciário, o Direito Processual terá a missão de disciplinar a técnica de demonstração concreta do valor de suas pretensões, enquanto que o Direito Civil determinará o valor intrínseco dos meios de prova; b) nos demais casos, incumbe exclusivamente ao Direito Civil definir quais são os meios de prova de que os interessados (não litigantes ou contendores) devem se valer para provar qualquer fato jurídico". (GAMA, 2007, p. 591).

11 "Art. 393. A confissão é irrevogável, mas pode ser anulada se decorreu de erro de fato ou de coação". 
documento particular escrito e assinado ou somente assinado presumem-se verdadeiras em relação ao signatário". ${ }^{12}$

Diante desse cenário, mais importante que forjar os âmbitos civil e processual da prova, ou ainda advogar seu caráter predominantemente material ou formal, ${ }^{13}$ afigura-se compreender o sentido da regulamentação da prova, tanto no Código Civil, quanto no Código de Processo Civil. Desse modo, ainda que persista o entendimento de que "a natureza das normas probatórias, como instrumento para a resolução de conflitos e a demonstração dos fatos em juízo, tem caráter predominantemente processual" (TARTUCE, 2006, p. 168),$^{14}$ mostra-se mais profícuo estabelecer, conforme a concepção sistemática do ordenamento, os pontos de interação entre essas fontes normativas. Ao propósito, não parece infundado atribuir à vetusta distinção entre fato social e fato jurídico ${ }^{15}$ a difusa afirmação de que as normas sobre a prova no Código Civil se limitam "ao aspecto substancial da prova, ou seja, daquilo que, em regra, deve influir sobre o regime dos negócios e atos jurídicos", ${ }^{16}$ de modo que sua aplicabilidade seria mais restrita em relação à disciplina processual. ${ }^{17}$

A rigor, todo fato social interessa ao direito, já que, plasmado pela tábua axiológica do sistema, interfere, ao menos potencialmente, na convivência social, encontrando-se, portanto, no espectro de incidência do ordenamento jurídico. ${ }^{18}$ Desse modo, "quando se fala em ato jurídico, o que se tem em vista é a relevância do acontecimento para o Direito" (VILLELA, 1982, p. 259), não sendo por isso mesmo suficiente a percepção de que a normativa do Código Civil possuiria aplicação limitada a certos fatos, conforme a classificação adotada. ${ }^{19}$

Investigando-se as razões da opção pela disciplina civil da prova - além do fato de representar reminiscência histórica da relação entre a forma e a prova do negócio jurídico -, nota-se a preocupação com a denominada "prova extrajudicial", tendo em vista que o Código de Processo Civil destinar-se-ia à regulamentação da prova exclusivamente no âmbito do processo judicial.

Nessa direção, observou-se em relação à disciplina da prova no Projeto do Código Civil de 2002: "com referência à prova, considerou-se que essa essencialmente se faz em juízo. Mas como também há a

12 No cotejo entre o Código Civil e o Código de Processo Civil verifica-se, com efeito, diversos dispositivos semelhantes ou destinados a regulamentar um mesmo aspecto na disciplina da prova. V., ao propósito, os seguintes artigos do CPC, que guardam relação com a disciplina do Código Civil: "Art. 413. O telegrama, o radiograma ou qualquer outro meio de transmissão tem a mesma força probatória do documento particular se o original constante da estação expedidora tiver sido assinado pelo remetente. Parágrafo único. A firma do remetente poderá ser reconhecida pelo tabelião, declarando-se essa circunstância no original depositado na estação expedidora. Art. 414. O telegrama ou o radiograma presume-se conforme com o original, provando as datas de sua expedição e de seu recebimento pelo destinatário. [...]. Art. 417. Os livros empresariais provam contra seu autor, sendo lícito ao empresário, todavia, demonstrar, por todos os meios permitidos em direito, que os lançamentos não correspondem à verdade dos fatos. Art. 418. Os livros empresariais que preencham os requisitos exigidos por lei provam a favor de seu autor no litígio entre empresários. [...]. Art. 422. Qualquer reprodução mecânica, como a fotográfica, a cinematográfica, a fonográfica ou de outra espécie, tem aptidão para fazer prova dos fatos ou das coisas representadas, se a sua conformidade com o documento original não for impugnada por aquele contra quem foi produzida. [...]. Art. 425. Fazem a mesma prova que os originais: I - as certidões textuais de qualquer peça dos autos, do protocolo das audiências ou de outro livro a cargo do escrivão ou do chefe de secretaria, se extraídas por ele ou sob sua vigilância e por ele subscritas; II - os traslados e as certidões extraídas por oficial público de instrumentos ou documentos lançados em suas notas; III - as reproduções dos documentos públicos, desde que autenticadas por oficial público ou conferidas em cartório com os respectivos originais; IV - as cópias reprográficas de peças do próprio processo judicial declaradas autênticas pelo advogado, sob sua responsabilidade pessoal, se não lhes for impugnada a autenticidade; $\mathrm{V}$ - os extratos digitais de bancos de dados públicos e privados, desde que atestado pelo seu emitente, sob as penas da lei, que as informações conferem com o que consta na origem; VI - as reproduções digitalizadas de qualquer documento público ou particular, quando juntadas aos autos pelos órgãos da justiça e seus auxiliares, pelo Ministério Público e seus auxiliares, pela Defensoria Pública e seus auxiliares, pelas procuradorias, pelas repartições públicas em geral e por advogados, ressalvada a alegação motivada e fundamentada de adulteração. $\S 1^{\circ}$. Os originais dos documentos digitalizados mencionados no inciso VI deverão ser preservados pelo seu detentor até o final do prazo para propositura de ação rescisória. $\S 2^{\circ}$. Tratando-se de cópia digital de título executivo extrajudicial ou de documento relevante à instrução do processo, o juiz poderá determinar seu depósito em cartório ou secretaria".

13 Para uma análise das diversas correntes sobre a natureza jurídica (material ou processual) da prova, v. Giannico (2005, p. 119-157); Rego (1985, p. 15-88).

14 Na mesma direção, v. Câmara (2006, p. 116-117).

15 Sobre este aspecto, já se afirmou que "parece arbitrário considerar alguns fatos simplesmente alheios ao direito, ou despidos de relevância ou pressupostos de eficácia, já que a experiência normativa alcança integralmente a vida social, mesmo os espaços de liberdade que o direito, valorando-os, preserva deliberadamente contra qualquer tipo de regulamentação" (TEPEDINO, 2014, p. 13).

16 Theodoro Júnior (2008, p. 459). V., ainda, Tartuce (2015, p. 171-173).

17 Em perspectiva contrária à restrição da incidência do Código Civil, já se destacou ser "injustificável, do ponto de vista lógico, a ideia de que as provas arroladas no art. 212 não possam referir-se a fatos simples” (MOREIRA, 2005, p. 101). No mesmo sentido: Gama (2007, p. 590).

18 Afirma Pietro Perlingieri (2009, p. 640): “'Fato' não é um termo com um único significado: o 'fato' objeto de exame de uma ciência natural não é o 'fato' objeto de uma ciência prática (como o direito), para a qual o fato é todo evento que invoque a ideia de convivência (ou do caráter relacional)".

19 Acerca da classificação dos fatos jurídicos, v. Tepedino (2014, p. 16). 
necessidade muitas vezes de prova extrajudicial, manteve-se a sua disciplina no Projeto" (ALVES, 1999). Considerando, portanto, que a prova dos fatos pode ser de extrema relevância também fora dos Tribunais, ${ }^{20}$ afirma-se a pertinência da regulamentação civil da prova (GAMA, 2007, p. 590-591; DIDIER JR., 2004, p. 30). Na legalidade constitucional, certo é que, diante de determinado suporte fático, o intérprete não deverá excluir aprioristicamente a aplicação das normas que disciplinam a prova, seja no Código Civil, seja no Código de Processo Civil. Antes, faz-se necessário, rejeitando-se a subsunção mecânica e acrítica das regras de um ou outro diploma, compor de forma harmoniosa as fontes normativas, tendo como fundamento central e critério valorativo a Constituição da República. ${ }^{21}$

\section{Prova e forma do negócio jurídico: a chamada forma ad probationem}

Como visto, o Código Civil, ao contrário do Código anterior, positivou a prova em título próprio, independente da regulamentação do negócio jurídico. A opção legislativa, contudo, não impediu que se mantivesse a confusão entre forma do negócio jurídico e prova dos fatos jurídicos. Ao tratar da forma dos negócios jurídicos, destaca-se em doutrina que a forma constitui o meio para exprimir a vontade interna (MONTEIRO, 2007, p. 292), de modo que "não há negócio sem forma" (AZEVEDO, 2002, p. 126). ${ }^{22}$ No que interessa ao controle de merecimento de tutela dos atos de autonomia privada, contudo, tratar da forma do negócio jurídico significa verificar por quais meios o ordenamento permite que a autonomia privada promova a autorregulamentação eficaz dos interesses.

No sistema atual, reafirmou-se o princípio da liberdade das formas, positivado no artigo 107 do Código Civil, segundo o qual "a validade da declaração de vontade não dependerá de forma especial, senão quando a lei expressamente a exigir". Desse modo, como se sabe, apenas nas hipóteses em que a lei exige determinada forma poder-se-á falar em requisito formal. Assim ocorre, por exemplo, nos contratos de doação (artigo 541 do Código Civil), de fiança (artigo 819 do Código Civil), e na transação (artigo 842 do Código Civil), em relação aos quais o Código expressamente exige forma específica. De outra parte, não prevendo a lei a adoção de determinada forma, preserva-se a liberdade para pactuar da forma que melhor convier ao interessado. ${ }^{23}$ Com isso, nos negócios não solenes, o acordo verbal pode gerar direitos e obrigações do mesmo modo que o acordo celebrado por escritura pública. Em relação à forma, portanto, o objeto central de investigação consiste em analisar se a forma adotada no negócio jurídico atende às exigências legais. Verificando-se que a forma adotada corresponde ao que determina a lei - obedecendo a

20 Nessa perspectiva, afirma Pontes de Miranda (2012, p. 523): "Dizer-se que prova é o ato judicial, ou processual, pelo qual o juiz se faz certo a respeito do fato controverso ou do assento duvidoso que os litigantes trazem a juízo (cf. Melo Freire, Institutiones, IV, 126: "Probatio est actusiudicialis, quo litigantes iudici de facto controverso, vel de redubiafidem in iudiciofaciunt') é processualizar-se, gritantemente, a prova. A adução, introdução ou representação da prova tanto pode ser em juízo quanto fora dele. O herdeiro paga as dívidas do decujo, que se lhe cobram, com as provas produzidas; e aquelas pessoas que têm muitos negócios exigem que se apresentem as faturas, com as provas, para que se lembrem das contas que hão de pagar. Pensar-se em prova judicial quando se fala de prova é apenas devido à importância espetacular do litígio, nas relações jurídicas entre os homens. As provas destinam-se a convencer da verdade; tal o fim". No Código Civil, pode-se mencionar, ilustrativamente, hipóteses em que a prova se mostra relevante fora do processo judicial. O artigo 74 prevê que a mudança de domicílio, transferindo a residência, opera-se "com a intenção manifesta de o mudar" e, em seu parágrafo único, estabelece que "a prova da intenção resultará do que declarar a pessoa às municipalidades dos lugares, que deixa, e para onde vai, ou, se tais declarações não fizer, da própria mudança, com as circunstâncias que a acompanharem". Da mesma forma o artigo 118, ao prever que "o representante é obrigado a provar às pessoas, com quem tratar em nome do representado, a sua qualidade e a extensão de seus poderes, sob pena de, não o fazendo, responder pelos atos que a estes excederem".

21 Na lição de Pietro Perlingieri (2002, p. 6), "o papel unificador do sistema, tanto nos seus aspectos mais tradicionalmente civilísticos quanto naqueles de relevância publicista, é desempenhado de maneira cada vez mais incisiva pelo Texto Constitucional [...]. A questão não reside na disposição topográfica (códigos, leis especiais), mas na correta individuação dos problemas. A tais problemas será necessário dar uma resposta, procurando-a no sistema como um todo".

22 Destaca o autor: "importa é não fazer a confusão elementar de entender que somente os negócios com forma prescrita é que têm forma, sem se dar conta de que todos eles, inclusive os de forma livre, hão de ter uma forma, do contrário, inexistiriam" (AZEVEDO, 2002, p. 126).

23 Não se trata, vale destacar, de raciocínio pautado na lógica "regra e exceção". Como observa Pietro Perlingieri (1987, p. 35-36), a concepção que sustenta a excepcionalidade do requisito formal de validade encontra-se arraigada na configuração da "autonomia negoziale come un valore in sé, quasi un dogma, e tutto ciò che è destinato a specificarlo come un limite esterno per di piú eccezionale. [...] l'autonomia non è il prius, la regola - come tale non bisgonosa di legittimazione -; e la forma vincolata dell'atto non è limite esterno, il posterius, eccezionale e indefettibilmente tassativo. [...] la funzione della prescrizione sulla forma può essere ispirata a ragioni di garanzia e di promozione di interessi e di valori anche se diversi dalla generica e formale libertà". O autor destaca que "ogni forma è disposta non per una funzione qualsiasi ma per una funzone che sia comunque costituzionalmente apprezzabile. Si tratta di esprimere non un giudizio di opportunità nell'àmbito di una discrezionalità riservata al legislatore ordinario ma di un giudizio di idoneità rispetto a interessi preminenti che supera una astratta valutazione in termini di ragionevolezza assoluta" (PERLINGIERI, 1987, p. 61). 
eventual especificação de forma para determinado negócio ou, quando não especificado, sendo celebrado por qualquer forma -, não deve haver dúvidas quanto à validade do negócio jurídico, esgotando-se aqui o controle relacionado à forma.

A prova, por sua vez, na medida em que se relaciona à comprovação de certo fato, não se confunde com a forma, embora com ela guarde pertinência, considerando que, se todos os fatos jurídicos se exteriorizam de alguma forma, a percepção dessa forma no meio social é que poderá servir como fonte de prova. ${ }^{24}$ Miguel Maria de Serpa Lopes (1989, p. 381) afirma, nessa direção, que, "a despeito da conexão íntima entre a forma e a prova do negócio jurídico, impõe-se não confundir as duas noções. Enquanto a forma é um conjunto de solenidades destinado a dar eficácia à declaração de vontade, a prova representa [...] o conjunto de meios comprobatórios da existência do ato."25

Estabelecida tal distinção, observa-se que, havendo requisito formal de validade do negócio jurídico, e vindo este a ter sua existência contestada, a comprovação do negócio apenas surtirá efeitos caso observe a forma exigida em lei. Assim, por exemplo, se o doador nega que tenha celebrado contrato de doação de automóvel de luxo, eventual esforço do donatário no sentido de comprovar o negócio por meio de testemunhas será em vão, tendo em vista que, não obstante possa comprovar o fato de que o doador se manifestou oralmente no sentido de doar o bem, tal fato não se qualifica como contrato de doação. ${ }^{26}$ Ao reverso, ausente qualquer requisito formal de validade do negócio, e vindo este a ter sua existência contestada, sua comprovação poderá se realizar por meio de qualquer prova lícita. ${ }^{27}$

Seguindo tal raciocínio, cumpre indagar acerca da tradicional classificação das formas em ad substantiam - ou ad solemnitatem - e ad probationem. Colhe-se na doutrina extensa controvérsia acerca dessa distinção. Afirma-se, de um lado, que

o rigor da lei no tocante ao requisito formal gradua-se ainda em atenção ao motivo que inspirou o legislador. Conforme o caso, ora é reclamado ad solemnitatem, e, então, diz-se que predomina sobre o fundo, não tendo nenhum valor a vontade que deixa de revestir a forma de emissão imposta pelo ordenamento jurídico ("forma dat esse rei"); ora é adotada ad probationem, e estabelece-se a necessidade dela para prova do negócio jurídico (PEREIRA, 2016a, p. 413-414). ${ }^{28}$

24 A relação entre forma e prova é destacada por Anderson Schreiber (2014, p. 98): "A forma do contrato desempenha historicamente uma dupla função: por um lado, alerta os contratantes para a seriedade do vínculo contratual, fazendo-os refletir sobre a contratação antes de conclui-la em definitivo. Por outro lado, serve, perante os próprios contratantes e a sociedade, como meio de prova da formação do contrato e do seu conteúdo". Manifesta-se em sentido semelhante Sílvio de Salvo Venosa (2005, p. 629), para quem formas são "fatores externos que fazem a vontade extravasar os limites do pensamento, do raciocínio singelo, que por si sós não podem ter efeito jurídico. É por meio da forma que existe a comunicação; tal comunicação ganhará contornos jurídicos dependendo da direção imposta pelo agente. Ao mesmo tempo que serve para exteriorizar a vontade, a forma serve de prova para o negócio jurídico".

25 Na lição de Washington de Barros Monteiro (2007, p. 292), "não se deve confundir a forma com a prova dos negócios jurídicos. A primeira é meio para exprimir a vontade interna; a segunda, meio para evidenciar a existência do negócio jurídico". No mesmo sentido, Sílvio de Salvo Venosa (2005, p. 631-632) destaca que não se confunde "forma com prova dos atos jurídicos. A forma é vista sob o aspecto estático; é aquele envoltório que reveste a manifestação de vontade. A prova é vista sob o aspecto dinâmico; serve para demonstrar a existência do ato". V., ainda, Humberto Theodoro Júnior (2008, p. 454), para quem prova "não é sinônimo de forma. Tem um sentido mais amplo: é qualquer meio de revelar a verdade de um fato".

26 Isso porque o artigo 541 do Código Civil prevê que "a doação far-se-á por escritura pública ou instrumento particular", ressalvando, no parágrafo único, que "a doação verbal será válida, se, versando sobre bens móveis e de pequeno valor, se lhe seguir incontinenti a tradição". Como explica San Tiago Dantas (s.d., p. 47-48), "todas as vezes que o ato se revestiu de certas formas reputadas essenciais para a sua validade, não se trata de saber se o juiz e convenceu ou não de sua existência, trata-se que sua existência não se opera por faltarem certos caracteres formais". Humberto Theodoro Júnior (2008, p. 469) afirma, nessa perspectiva, que, "quando o ato é solene, por imposição da lei, sua prova não pode ser feita senão por aquela forma decorrente das solenidades que lhe dão validade. Enquanto não provada a forma imposta pela lei, não se pode ter como válido o negócio e, consequentemente, não se pode dele extrair os efeitos jurídicos desejados. Somente pela forma definida na lei o negócio de aperfeiçoa e assume existência válida; e somente pelos elementos que configuram a tipicidade legal é que sua prova haverá de ser feita. De nada vale, por exemplo, a demonstração por testemunha ou documento particular do domínio sobre determinado bem imóvel, porque sua aquisição somente se dá por meio do registro do título aquisitivo no Registro Público competente. Em se tratando, porém, de ato jurídico de forma livre, os fatos que o geraram ou que influíram em sua existência e em seu conteúdo podem ser provados, segundo o art. 212, mediante: I - confissão; II - documento; III - testemunha; IV - presunção; V - perícia". Destaca que, "tratando-se de negócio jurídico não-formal, qualquer meio de prova é permitido pela ordem jurídica desde que não seja por ela proibido ou restringido" (THEODORO JÚNIOR, 2008, p. 469).

27 Com efeito, a Constituição da República veda, no artigo $5^{\circ}, \mathrm{LVI}$, as provas obtidas por meios ilícitos: "são inadmissíveis, no processo, as provas obtidas por meios ilícitos". O CPC estabelece, no artigo 369, que "as partes têm o direito de empregar todos os meios legais, bem como os moralmente legítimos, ainda que não especificados neste Código, para provar a verdade dos fatos em que se funda o pedido ou a defesa e influir eficazmente na convicção do juiz". Quanto ao Código Civil, é pacífico na doutrina que o rol constante do artigo 212 possui caráter exemplificativo. Por todos, v. Barbosa Moreira (2005, p. 110-111).

28 Na mesma direção, Pontes de Miranda (2012, p. 451): "Se a lei exige ao ato jurídico a forma escrita, tem-se de perguntar se a exigiu como pressuposto necessário, caso em que a falta da forma escrita é óbice à entrada da manifestação de vontade no mundo jurídico e a defeituosidade causa de nulidade, ou se apenas estabeleceu regra jurídica de prova". 
De acordo com essa perspectiva, portanto, a forma, além das hipóteses em que se afigura essencial à validade do negócio jurídico, poderia ser prevista como exigência legal para sua prova. ${ }^{29}$

Em posição contrária, critica-se veementemente a distinção. Nessa direção, Clovis Bevilaqua (1956, p. 311) já afirmava que a distinção seria a "sobrevivência de inúteis sutilezas de antigos juristas", não havendo, "na sistemática do Código Civil, formas somente para a prova dos atos. Estes ou têm uma forma especial exigida por lei ou se provam pelos meios admitidos em direito. A forma ou é preestabelecida ou é livre". ${ }^{30}$ Com efeito, mesmo na vigência do Código Civil de 1916, a doutrina já se opunha à forma ad probationem, esclarecendo que "não há formalidade solene para a prova do ato, uma vez que ou este tem uma forma especial exigida por lei, ou pode ser provado pelos meios admitidos em Direito" (SANTOS, 1963, p. 118). ${ }^{31}$ Interessante notar as lições de San Tiago Dantas (2001, p. 221-222) sobre a questão, ao afirmar: "raciocinando dentro do direito civil brasileiro não acho nenhum cabimento para esta distinção, pois que, se não podemos provar um ato senão de certo modo, este ato, praticamente, não existe". ${ }^{32}$

Aos questionamentos erigidos em face da forma ad probationem, contra argumenta-se que a lei teria instituído, em algumas hipóteses, exigência de forma para que se pudesse provar determinado fato. ${ }^{33}$ Entre os exemplos que comprovariam a alegada "formalidade ad probationem", estariam "a lavratura do assento de casamento no livro de registro" (GONÇALVES, 2010, p. 362) e a exigência do artigo 227, caput, do Código Civil em relação aos negócios jurídicos cujo valor exceda o valor do décuplo do salário mínimo (PEREIRA, 2016a, p. 413-414; WALD, 2009, p. 223).

Em relação ao primeiro, não parece que se refira a ato de forma livre, tendo em vista que o casamento, como se sabe, consiste em ato jurídico solene (TEPEDINO, 2008, p. 428-431). ${ }^{34}$ Quanto ao segundo exemplo, revela-se significativo que o Código de Processo Civil tenha revogado o caput do artigo 227 do Código Civil, ${ }^{35}$ a demonstrar o comprometimento contemporâneo com o sistema do livre convencimento motivado, ${ }^{36}$ conforme prevê o artigo 371 do diploma processual: "o juiz apreciará a prova constante dos autos, independentemente do sujeito que a tiver promovido, e indicará na decisão as razões da formação de seu convencimento". ${ }^{37}$

29 Para Arnoldo Wald (2009, p. 223), "algumas vezes, a forma é essencial à validade do negócio jurídico, embora a declaração de vontade não dependa, em tese, de forma especial, senão quando a lei expressamente a exija (art. 107 do CC). Em outras situações, a forma é mero meio de prova. [...]. Estabelece, assim, a nossa legislação uma distinção entre as formalidades necessárias para a existência do negócio jurídico e as exigidas para sua prova".

30 Clovis Bevilaqua (1956, p. 311) observava que, "no Código Civil, não se encontram reflexos dessas distinções. É certo que por amor delas, eliminou-se um artigo do Projeto primitivo, que proclamava a identidade entre a prova exigida por lei e a forma especial do ato (art. 142). Mas, não obstante, a doutrina, que ressalta de todo este capítulo, é a que aquele Projeto exprimia na tese eliminada".

31 O autor, alinhando-se à crítica de Clovis Bevilaqua (1963, p. 118), afirmava que "a distinção que se fazia no Direito antigo entre essas formalidades não se justifica mais e nem o Código a admite”. Na mesma direção, v. Serpa Lopes (1989, p. 380); Monteiro (2007, p. 292); Gomes (2016, p. 297); Rodrigues (2003, p. 177); Azevedo (2004, p. 252-253).

32 Em seguida, San Tiago Dantas (2001, p. 221-222) desafiava seus alunos: "Em todo caso, podem investigar um pouco este problema como assunto que lhes proponho para ocupar alguns dos senhores no seminário, a saber, se existe algum fundamento no direito civil brasileiro para diferenciar os atos solenes em atos substanciais e ad probationem. Não dou esta minha opinião como definitiva, mas tenho para mim que não há nenhuma necessidade de fazer esta distinção, que todos os autores estrangeiros fazem, e que é obedecida por muitos dos autores nacionais".

33 Nesta hipótese, para Caio Mário da Silva Pereira (2016a, p. 413-414), "a forma não sobreleva ao fundo, nem se integra na constituição do ato, requerendo-o como meio de evidência tão somente. O negócio jurídico é válido em si mesmo, mas não pode ser provado senão pela confissão da parte, a quem é oposto, ou por sua execução espontânea, que é uma espécie de confissão extrajudicial".

34 Além disso, o artigo 1.543, parágrafo único, do Código Civil prevê que "justificada a falta ou perda do registro civil, é admissível qualquer outra espécie de prova".

35 O artigo revogado estatuía: "Salvo os casos expressos, a prova exclusivamente testemunhal só se admite nos negócios jurídicos cujo valor não ultrapasse o décuplo do maior salário mínimo vigente no País ao tempo em que foram celebrados". Observa-se que, mesmo na vigência do artigo, sua restrição já vinha sendo relativizada na jurisprudência (BRASIL. STJ. $3^{\text {a }}$ T. REsp 895.792/RJ. Rel. Min. Paulo de Tarso Sanseverino, julg. 7.4.2011). Acerca do parágrafo único do artigo 227, que não fora expressamente revogado pelo CPC, Flávio Tartuce (2015, p. 204) observa que "a prova testemunhal passa a ser utilizada como meio de prova de negócios jurídicos de qualquer valor", sendo injustificada a permanência do parágrafo único do artigo 227, vez que "a prova testemunhal não será prova subsidiária, mas sempre meio principal e em todas as situações concretas, não importando mais o valor do negócio jurídico correspondente".

36 O princípio do livre convencimento motivado vem constantemente afirmado na jurisprudência do Superior Tribunal de Justiça. V., ilustrativamente, BRASIL. STJ. $6^{a}$ T. REsp 783.697/GO. Rel. Min. Nilson Naves, julg. 20.6.2006; BRASIL. STJ. $1^{\text {a }}$ T. AgRg no REsp 1.092.615/SP. Rel. Min. Benedito Gonçalves, julg. 9.3.2010.

37 "O sistema processual de avaliação da prova não é tarifado, podendo as provas ser objeto de apreciação e valoração sem quaisquer amarras" (GAJARDONI et al., 2016, p. 225). Ainda que se mantenham limitações probatórias, a exemplo da vedação do artigo 228 do Código Civil às testemunhas incapazes, impedidas ou suspeitas, seria impróprio qualificar tais limitações como forma ad probationem. As restrições se relacionam unicamente à credibilidade da prova em si, sem qualquer relação com a forma dos negócios jurídicos. Além disso, o próprio Código Civil passa a admitir que, "para a prova de fatos que só elas conheçam, pode o juiz admitir o depoimento das pessoas a que se refere este artigo" (artigo $228, \S 1^{\circ}$ ). 
A confusão realizada entre forma e prova ganha aqui novamente contornos bem definidos, o que se comprova com a identidade, proposta em doutrina, entre "prova de natureza especial" e "forma ad substantiam", isto é, a exigência de determinada fonte de prova seria equivalente ao requisito de forma. ${ }^{38}$ Nessa direção, afirma-se que a prova exigida em lei - o que, como se viu até o momento, seria exatamente a forma ad probationem - "se confunde com os negócios jurídicos solenes" (GAMA, 2007, p. 594). Em definitivo, acaba-se por afirmar, por via oblíqua, que forma ad probationem é o mesmo que forma ad substantiam.

Mesmo em relação aos autores que sustentam a forma ad probationem, nota-se certa dificuldade diante da possibilidade de suprimir a prova de fato a que a lei não atribua forma especial como requisito de validade. Caio Mário da Silva Pereira (2011, p. 420-421), por exemplo, já se manifestou, ainda na vigência do Código de 1916, no sentido de que:

afora os casos em que a lei estabelece rigidamente os meios probatórios admissíveis, como ocorre por exemplo na menção do artigo 134 do Código Civil ao estatuir quando o instrumento público é da substância do ato, ou o artigo 132 ao vincular a anuência ao modo de prova do negócio jurídico, afora em casos como tais, vige em direito a maior liberdade para a comprovação das declarações volitivas, como dos fatos em geral.

Ao examinar caso no qual se debatia essa questão, reconheceu o autor que a observância da forma acordada pelas partes para registrar os fatos controversos "seria de molde a produzir desde logo a evidência desejada", o que, porém, não impediria a comprovação por outros meios. ${ }^{39}$

Parece ser essa a solução mais acertada em relação às hipóteses em que a lei especifica a fonte de prova adequada à comprovação de certo fato. ${ }^{40}$ Desse modo, verificando-se que se trata de ato não solene - de forma livre, portanto -, a indicação legal da fonte de prova pode representar, no máximo, a preferência do legislador, sem, contudo, excluir a possibilidade de prova por outros meios. Portanto, o efeito mais evidente consiste em que, apresentada a prova indicada na lei, inverte-se o ônus de comprovação do fato, criando-se presunção relativa de ocorrência do fato jurídico. ${ }^{41}$

A rejeição à categoria das formas ad probationem encontra amparo também na jurisprudência do Superior Tribunal de Justiça, contribuindo para precisar conceitualmente o que configura prova do fato jurídico e o que representa exigência de forma do negócio jurídico. No julgamento do REsp 913.008/RJ, a Quarta Turma do STJ debateu a questão relativa ao artigo 9, parágrafo único, da Lei n. 9.609/98, que prevê, no contrato de licença de uso de programa de computador, que "na hipótese de eventual inexistência

38 Nessa direção, Carlos Santos de Oliveira (2013, p. 502) sustenta que, "nas hipóteses de prova de natureza especial, nenhuma outra prova, por mais especial que seja, poderá suprir a falta do instrumento que é a substância do próprio ato". Fala-se até mesmo em "prova ad solemnitatem" (GIANNICO, 2005, p. 104-107).

39 No caso, discutia-se, em contrato de empreitada, a prova dos atrasos do dono da obra na entrega dos projetos, tendo em vista que não houve registro de diversas irregularidades no "Diário das Obras". Caio Mário da Silva Pereira (2011, p. 421) esclareceu que, "houvesse a Empreiteira registrado no "Diário das Obras" os fatos de que se queixa, e a sua simples leitura seria de molde a produzir desde logo a evidência desejada. Não o tendo feito a não ser no começo dos serviços, não está porém inibida de comprovar através um processo mais complexo, mas nem por isso menos hábil, que é a rememoração das circunstâncias contrárias à correlação obrigacional advinda do contrato. Efetuando o levantamento lastreado em outros fatores dotados de autenticidade, terá logrado a comprovação das circunstâncias fáticas danosas, suficientemente para convencer e atingir o mesmo resultado".

40 Ilustrativamente, vale remeter ao artigo 646 do Código Civil, que estabelece: "O depósito voluntário provar-se-á por escrito". A respeito do contrato de depósito, a doutrina considera tratar-se de contrato no qual a forma não constitui requisito de validade (LOPES, 1993, p. 260; TEPEDINO; BARBOZA; MORAES, 2012, p. 409), o que não impede a afirmação, de outra parte, de que a forma seria ad probationem (PEREIRA, 2016b, p. 340). Percebe-se, contudo, a perplexidade da doutrina diante da possibilidade de se negar tutela ao contrato de depósito na hipótese em que a parte não possua o documento - o qual, vale destacar, não se afigura necessário à validade do contrato -, embora possa comprovar o contrato mediante o depoimento de testemunhas. Diante disso, afirma-se que "o instrumento do depósito poderá ser suprido por outras provas", de modo que, se o depositante perder seu título, poderá recorrer a outra prova (BEVILAQUA, 1957, p. 17; SANTOS, 1961, p. 79). Conclui-se que a previsão do artigo 646 do Código Civil não exclui a possibilidade de prova do depósito por outras fontes que não a escrita, a corroborar a crítica às chamadas formas ad probationem. O mesmo se poderia afirmar, à evidência, quanto à redação do artigo 1.063 do Código Civil: "A filiação prova-se pela certidão do termo de nascimento registrada no Registro Civil”. Como se sabe, a ausência da certidão do termo de nascimento não impede a prova da filiação por outros meios.

41 Nessa direção, v. BRASIL. TJRJ. 10a C.C. Ap. Cív. 0070539-18.2002.8.19.0001. Rel. Des. Celso Luiz de Matos Peres, julg. 27.5.2009. No caso, o depositante exigia a restituição do bem, exibindo o documento que comprovaria o depósito. O depositário alegava, porém, "não ter havido qualquer depósito, argumentando que forneceu apenas simples declaração quanto ao depósito da referida quantia visando facilitar as atividades de 'marchand' desenvolvidas". O TJRJ, dando provimento ao pleito do depositante, destacou, contudo, que "a emissão do aludido comprovante de depósito pela apelada, operou a inversão do ônus da prova, fato para o qual a mesma não atentou". 
do contrato referido no caput deste artigo, o documento fiscal relativo à aquisição ou licenciamento de cópia servirá para comprovação da regularidade do seu uso". Segundo a Corte Superior,

conquanto o referido artigo faça remissão expressa ao contrato de licença e ao documento fiscal como meios hábeis de provar a regularidade do programa de computador, é igualmente certo que o dispositivo não excluiu expressamente outros elementos de prova, que possam ser apresentados pelas partes para demonstração da verdade dos fatos. Inexistindo, na letra da lei, óbice expresso à utilização de outros meios, impõe-se, igualmente, que o dispositivo seja interpretado de forma lógico-sistemática, à luz de seu contexto normativo. ${ }^{42}$

Em outro caso emblemático, o STJ analisou o artigo 27 da Lei n. 4.886/65, que prevê os elementos que deverão constar do contrato de representação comercial, estabelecendo que a cláusula de exclusividade deve ser expressamente pactuada entre as partes. A Corte, interpretando tal exigência, afirmou que, embora deva ser expressa, isso não significa que sua formalização ocorra necessariamente por escrito. Com isso, "a demonstração da existência da cláusula de exclusividade pode ser feita mediante a produção de prova testemunhal”. ${ }^{43}$ Como se percebe, diante de ato em relação ao qual não há exigência de forma - o que somente poderá se verificar com a interpretação da normativa incidente,$-{ }^{44}$ torna-se injustificada qualquer exigência formal para a prova do ato. A limitação a determinadas fontes de prova, como na hipótese das testemunhas incapazes, impedidas ou suspeitas (artigos 228 do Código Civil e 447 do Código de Processo Civil), fundamenta-se na credibilidade intrínseca à fonte de prova, sem qualquer relação com a forma dos negócios jurídicos, sendo, portanto, imprecisa a referência à chamada "forma ad probationem".

\section{$30 \mathrm{CPC} / 2015$, a prova documental e as novas tecnologias}

Na esteira das interações entre o Código Civil e o Código de Processo Civil, assume relevância a questão das provas eletrônicas, especialmente quanto aos documentos produzidos no meio digital. ${ }^{45}$ A prova documental, objeto dos artigos 215 a 226 do Código Civil, é considerada pela doutrina a mais nobre das provas (PEREIRA, 2016a, p. 497; GAMA, 2007, p. 597). Exige-se, por isso mesmo, cautela diante do que já se afirmou constituir a "grande crise de identidade" da prova documental, provocada com a difusão dos documentos eletrônicos (GRECO, 2005, p. 385). ${ }^{46} \mathrm{O}$ CPC, embora dedique três artigos

42 BRASIL. STJ. 4ª T. REsp 913.008/RJ. Rel. p/ Acórdão Min. Luis Felipe Salomão, julg. 25.8.2009. Para Bruno Lewicki (2011, p. 223), o caso “serve como possível retrato da tardia superação de um quase inconsciente fetiche pela prova legal, o qual se manifestaria mesmo em ocasiões em que o legislador não optou com toda clareza pela restrição das provas possíveis".

43 BRASIL. STJ. REsp 846.543/RS. 3 ${ }^{a}$ T. Rel. Min. Paulo de Tarso Sanseverino, julg. 5.4.2011: "Muito embora o enunciado normativo do art. 27 da Lei 4.886/65, alterado pela Lei 8.420/92, enumere os elementos obrigatórios que devem constar do contrato de representação comercial quando realizado por escrito, não há dispositivo legal tampouco entendimento jurisprudencial que imponha uma determinada forma, vedando a celebração de ajuste verbal entre as partes. Com isso, em se tratando de contrato celebrado verbalmente, admite-se a comprovação das cláusulas pactuadas entre as partes contratantes por todos os meios em direito admitidos, tal como autoriza o art. 212 do CC/02, combinado com os artigos 400 e segs. do CPC".

44 Como visto, deve-se evitar a concepção da forma especial como requisito excepcional. Como adverte Pietro Perlingieri (1987, p. 23), "la natura derogabile o inderogabile della singola norma sulla forma degli atti è non un prius indefettibile ma un risultato dell'interpretazione, la quale tiene conto dell'interesse e del valore tutelati dalla disposizione normativa, della intensità della sua rilevanza e delle garanzie richieste per la eventuale autoregolamentazione delle parti anche nel rispetto delle circostanze della perculiare incidenza che $i$ soggetti concreti hanno nella valutazione dell'ordinamento giuridico". Desse modo, uma disposição que estabelece hipótese de "forma da prova" poderá, conforme o caso, ser interpretada como forma ad substantiam.

45 Cumpre observar, porém, que as novas tecnologias não dizem respeito apenas à prova documental. Ilustrativamente, o CPC regulamenta o depoimento da parte e da testemunha por videoconferência (artigo 385, § $3^{\circ}$, e artigo $453, \S 1^{\circ}$ ).

46 Humberto Theodoro Júnior (2008, p. 571-573) afirma que "a evolução dos meios de comunicação, com o advento da eletrônica e dos computadores na vida mercantil, tornou insuficientes as regras legais de documentação e autenticação das declarações de vontade, já que estas, basicamente, se fundam na autenticação pela assinatura do declarante (sistema que literalmente se mantém nos art. 219 e 221 do novo Código Civil). [...]. Os computadores e a internet absorveram a imensa maioria das operações bancárias e seu emprego generalizou-se no comércio internacional. Os mais significativos negócios, no plano empresarial, se ajustam e se executam por via eletrônica, sem assinatura manual alguma das partes". 
aos documentos eletrônicos, ${ }^{47}$ deixou ao juiz e às leis especiais a responsabilidade pela apreciação dos principais problemas relativos à autenticidade e à produção da prova documental eletrônica. ${ }^{48}$ Deve-se observar, por outro lado, que a questão das provas eletrônicas precede o CPC/2015.

O Código Civil, tendo disciplinado o telegrama como meio de comunicação à distância, não escapou às críticas da doutrina quanto à sua defasagem em relação aos avanços tecnológicos na matéria (GAMA, 2007, p. 601). No entanto, a construção da norma extraída do artigo 225 do Código Civil permitiu que se acolhesse o documento eletrônico. Com efeito, aludido artigo, ao referir-se às reproduções eletrônicas de fatos ou de coisas, levou à consagração do documento eletrônico como fonte de prova ${ }^{49}$ afirmando-se, nessa direção, que o Código Civil teria admitido o documento eletrônico como documento particular. ${ }^{50}$

O artigo 225 do Código Civil encontra correspondência no artigo 422 do CPC, o qual, por seu turno, regulamenta outros aspectos do documento eletrônico. $\mathrm{O} \S 3^{\circ}$, por exemplo, reconhece a forma impressa ${ }^{51}$ do e-mail como fonte de prova incluída entre as reproduções mecânicas de fatos ou coisas..$^{52} \mathrm{O} \S 1^{\circ}$ prevê que "as fotografias digitais e as extraídas da rede mundial de computadores fazem prova das imagens que reproduzem" e que, caso seja impugnado o documento, torna-se necessária a apresentação da respectiva autenticação eletrônica ou a realização de perícia. ${ }^{53}$ Parece, portanto, consolidada a viabilidade do documento eletrônico como fonte de prova também no diploma processual.

Todavia, importa destacar que, no âmbito dos documentos particulares, o caput do artigo 221 do Código Civil menciona a assinatura como requisito para que o documento particular se constitua como prova das "obrigações convencionais de qualquer valor" e, da mesma forma, o caput do artigo 408 do CPC prevê que "as declarações constantes do documento particular escrito e assinado ou somente assinado presumem-se verdadeiras em relação ao signatário”. Nota-se nos artigos a preocupação em assegurar a possibilidade de identificação dos emitentes das declarações de vontade, como forma de controlar a autenticidade da prova documental. O parágrafo único do artigo 221 do Código Civil, por sua vez, estatui que "a prova do instrumento particular pode suprir-se pelas outras de caráter legal", o que seria suficiente à conclusão quanto à viabilidade do documento eletrônico, sendo perfeitamente possível, em tal perspectiva,

47 "Art. 439. A utilização de documentos eletrônicos no processo convencional dependerá de sua conversão à forma impressa e da verificação de sua autenticidade, na forma da lei. Art. 440. O juiz apreciará o valor probante do documento eletrônico não convertido, assegurado às partes o acesso ao seu teor. Art. 441. Serão admitidos documentos eletrônicos produzidos e conservados com a observância da legislação específica".

48 Em perspectiva crítica, afirma-se que, "infelizmente, o Novo Código praticamente não enfrenta as novas tecnologias: ainda que exista alguma regulamentação quanto ao tema, ela é tímida. E não há como justificar isso em um Código do século XXI. Considerando a grande revolução tecnológica nas últimas décadas, isso significa que o Código já nasce defasado. O melhor exemplo disso é o Código seguir mencionando figuras como telegrama e radiograma" (GAJARDONI et al., 2016, p. 364).

49 "Art. 225: As reproduções fotográficas, cinematográficas, os registros fonográficos e, em geral, quaisquer outras reproduções mecânicas ou eletrônicas de fatos ou de coisas fazem prova plena destes, se a parte, contra quem forem exibidos, não lhes impugnar a exatidão".

50 Para Carlos Santos de Oliveira (2013, p. 507), "o documento eletrônico é equiparado a documento particular. Sua validade como prova vem ganhando espaço, tanto na doutrina, como na jurisprudência. O documento eletrônico é aquele emitido via computador, como o e-mail, ou a impressão de determinado diálogo realizado em uma rede social. [...]. Assim, não havendo impugnação o documento eletrônico servirá como meio de prova. Caso haja impugnação, a constituição da prova mediante a exibição de documento eletrônico dependerá da análise de vários outros elementos". Segundo o autor, com o artigo 225 o Código Civil "deu um grande passo no sentido da modernidade, visto que por reproduções eletrônicas podemos entender a comunicação por fax, via e-mail e internet, bem como arquivos eletrônicos” (OLIVEIRA, 2013, p. 529).

51 A regulamentação da prova eletrônica no CPC se manteve atrelada à tradição do processo convencional (físico), de modo que a referência à forma impressa, presente em diversos artigos, deve ser relativizada, tendo em vista a expansão do processo eletrônico. Critica-se, nessa direção, que tais dispositivos, ao mencionarem a "forma impressa", "regulam o passado: um documento eletrônico sendo juntado a autos físicos" (GAJARDONI et al., 2016, p. 435).

52 "Art. 422. Qualquer reprodução mecânica, como a fotográfica, a cinematográfica, a fonográfica ou de outra espécie, tem aptidão para fazer prova dos fatos ou das coisas representadas, se a sua conformidade com o documento original não for impugnada por aquele contra quem foi produzida. [...] § $3^{\circ}$. Aplica-se o disposto neste artigo à forma impressa de mensagem eletrônica".

53 "Art. 422. [...] $\S 1^{\circ}$. As fotografias digitais e as extraídas da rede mundial de computadores fazem prova das imagens que reproduzem, devendo, se impugnadas, ser apresentada a respectiva autenticação eletrônica ou, não sendo possível, realizada perícia”. 
"seu uso para a comprovação da declaração negocial" (THEODORO JÚNIOR, 2008, p. 573), ${ }^{54}$ desde que preencha os requisitos de "inalterabilidade do teor", "identificabilidade da autoria" 55 e "tempestividade controlável".

Certo é que, na dinâmica do ambiente virtual, desenvolvem-se cada vez mais as relações sociais, tornando-se comum o aperfeiçoamento do vínculo obrigacional pelo simples envio de mensagem eletrônica. Do e-mail ao WhatsApp ou Telegram, verifica-se que a comunicação eletrônica se apresenta como protagonista da influência das novas tecnologias na vida cotidiana. Do mesmo modo, o chamado e-commerce difunde-se em larga escala, banalizando a conclusão de negócios cuja prova consiste, muitas vezes, na impressão de uma tela ou página virtual exibida após a confirmação da contratação. Afigura-se inevitável, nesse contexto, reconhecer a importância, como possíveis fontes de prova, dos documentos puramente eletrônicos, independentemente de assinatura, como no caso das cópias impressas de páginas virtuais e mensagens eletrônicas. ${ }^{56}$

Em consonância com essa orientação, já foram aprovados, no âmbito das Jornadas de Direito Civil do Conselho da Justiça Federal, três enunciados relevantes quanto aos documentos eletrônicos. ${ }^{57}$ Nos

54 A questão dos documentos eletrônicos sem assinatura ou certificação digital foi analisada em julgado do TJRJ. No caso, discutia-se a celebração de contrato de depósito de materiais de construção. Sustentava uma das partes que os documentos que fundamentavam a cobrança não poderiam ser considerados como fonte de prova das obrigações contratuais, por lhes faltar a assinatura das partes. O TJRJ, contudo, afirmou que, "apesar de apócrifo, o instrumento particular de contrato de depósito de materiais de construção constante de fls. 30/31 restou corroborado pelas comunicações eletrônicas formalizadas pelas partes, inexistindo qualquer irregularidade a respeito" (RIO DE JANEIRO. TJRJ. 8ª C.C., Ap. Cív. 0008881-67.2010.8.19.0209, Rel. Des. Norma Suely Fonseca Quintes, julg. 4.10.2016). A legitimidade de documentos extraídos da rede mundial de computadores, sem que deles conte qualquer assinatura ou certificação eletrônica, também já foi apreciada no STJ, notadamente quanto à possibilidade de instrução do agravo de instrumento com "cópia da decisão agravada sem assinatura do juiz, retirada da Internet". A Corte, que possuía jurisprudência no sentido que peças extraídas da internet utilizadas na formação do agravo de instrumento necessitam de certificação de sua origem para serem aceitas, decidiu pela admissão da cópia extraída da internet como válida à instrução do agravo, tendo em que vista que "os avanços tecnológicos vêm, gradativamente, modificando as rígidas formalidades processuais anteriormente exigidas" e que, no caso, seria "possível se aferir por outros elementos que a origem do documento retirado da Internet é o site do TJ/RS" (BRASIL. STJ. 3a T. REsp 1.073.015/RS. Rel. Min Nancy Andrighi, julg. 21.10.2008). A Corte também já reconheceu que a apresentação de e-mail pode ser suficiente à configuração de prova pré-constituída de ato coator em mandado de segurança impetrado em razão de ato que inabilitou o impetrante de concurso público. Segundo o STJ, no caso a exclusão estaria "devidamente comprovada através de comunicação eletrônica (e-mail) recebida, pelo recorrente, em sua caixa de correio eletrônico. Deveras, esse documento tem a propriedade de comprovar o ato coator e as consequências que dele derivam, o que torna despicienda a juntada do edital. Logo, ressoa inequívoco que o writ ofmandamus está guarnecido de prova pré-constituída" (BRASIL. STJ. 1ª T. RMS 2.907/AC. Rel. Min BeneditoGonçalves, julg. 25.5.2010).

55 Sobre este aspecto, destaca-se, nos documentos eletrônicos, a possibilidade de assinatura ou firma eletrônica, cada vez mais usual em certos segmentos, como, por exemplo, a advocacia. Guilherme Magalhães Martins (2003, p. 67-68) afirma, sobre o tema, que "a própria noção de assinatura passa por uma redefinição, a partir da sua função, e não a partir da sua forma, de modo não só a possibilitar a verificação da capacidade jurídica dos contratantes, como também melhor assegurar o cumprimento das obrigações relativas a cada uma das partes. Configura-se, assim, a prova da expressão do consentimento pelo meio eletrônico, ao qual deve ser equiparada a forma escrita exigida pela lei para determinados atos".

56 Nesta linha, Anderson Schreiber (2014, p 98-99) observa que "em um passado recente, os juristas brasileiros (como, de resto, os juristas de todo o mundo) discutiam se tais impressões, cópias ou documentos digitais tinham ou não validade como meio de prova, constituíam ou não meros indícios e outras questões que o avanço maciço da cultura digital parece ter tornado um tanto folclóricas. Em que pesem as dificuldades do sistema judiciário em lidar com documentos puramente eletrônicos e a suspeita quase instintiva que recaía, até pouco tempo, sobre cópias impressas de páginas virtuais e emails, não parece haver dúvida, atualmente, de que todos esses instrumentos devem ser admitidos como meios probatórios dos direitos discutidos em juízo".

57 Já na I Jornada de Direito Civil, aprovou-se o enunciado n. 18 nos seguintes termos: "A 'quitação regular' referida no art. 319 do novo Código Civil engloba a quitação dada por meios eletrônicos ou por quaisquer formas de 'comunicação a distância', assim entendida aquela que permite ajustar negócios jurídicos e praticar atos jurídicos sem a presença corpórea simultânea das partes ou de seus representantes". Da IV Jornada de Direito Civil extrai-se o enunciado n. 297, segundo o qual "o documento eletrônico tem valor probante, desde que seja apto a conservar a integridade de seu conteúdo e idôneo a apontar sua autoria, independentemente da tecnologia empregada". Especificamente relacionado à interpretação do artigo 225 do Código Civil, o enunciado n. 298, aprovado também na IV Jornada, prevê que "os arquivos eletrônicos incluem-se no conceito de "reproduções eletrônicas de fatos ou de coisas' do art. 225 do Código Civil, aos quais deve ser aplicado o regime jurídico da prova documental”. Tais enunciados têm auxiliado os Tribunais diante das controvérsias concernentes ao documento eletrônico, como se evidencia no acórdão do TJSP que, citando os enunciados 297 e 298 do Conselho de Justiça Federal, afirmou que a origem eletrônica "não afasta o valor probante do documento" (SÃO PAULO. TJSP. 20 C. C. Ap. Cív, 0018518-77.2010.8.26.0005. Rel Des. Maria Lúcia Pizzotti, julg. 27.08.2012). No Superior Tribunal de Justiça, a admissibilidade das provas oriundas do ambiente eletrônico a partir da interpretação do artigo 225 do Código Civil foi reconhecida no julgamento do REsp 1.381.603/MS, de 2016. Segundo o STJ, "no atual estágio da sociedade, há uma forte tendência de diminuição de documentos produzidos em meio físico, reduzindo consideravelmente o uso do papel. Tal constatação também se mostra evidente no âmbito das relações comerciais, cujas tratativas são realizadas, em boa parte, por meio eletrônico, bastando lembrar os serviços bancários online (internet banking). Nesse contexto, nota-se que a legislação brasileira, ainda sob à luz do CPC de 1.973, não proíbe a utilização de provas oriundas de meio eletrônico. No ponto, o Código Civil de 2.002, em seu art. 225, preceitua que 'as reproduções fotográficas, cinematográficas, os registros fonográficos e, em geral, quaisquer outras reproduções mecânicas ou eletrônicas de fatos ou de coisas fazem prova plena destes, se a parte, contra quem forem exibidos, não lhes impugnar a exatidão'. Por oportuno, o enunciado n. 297, aprovado na IV Jornada de Direito Civil (CJF/STJ) destaca que 'o documento eletrônico tem valor probante, desde que seja apto a conservar a integridade de seu conteúdo e idôneo a apontar sua autoria, independentemente da tecnologia empregada'. Com essa mesma linha de raciocínio, veja-se o enunciado n. 298: 'Os arquivos eletrônicos incluem-se no conceito de 'reproduções eletrônicas de fatos e coisa', do art. 225 do Código Civil, aos quais deve ser aplicado o regime jurídico da prova documental'". A Corte também abordou, neste julgado, os desafios quanto ao valor probante das mensagens eletrônicas: "o correio eletrônico (e-mail, abreviatura de eletronic mail) é serviço que permite a troca de mensagens e arquivos por meio de sistemas de comunicações eletrônicas, a exemplo dos computadores, tablets e smartphones. [...]. Quanto à sua força probante, o maior questionamento está adstrito ao campo da veracidade e da autenticidade das informações, principalmente sobre a propriedade de determinado endereço de e-mail. [...] a dúvida que pode surgir sobre a autenticidade do correio eletrônico deve ser avaliada pelo magistrado no exame do caso concreto, cabendo ao demandado, se assim o quiser, apresentar os embargos para questionar a idoneidade dos e-mails utilizados pelo autor para sustentar a existência da relação jurídica e o eventual inadimplemento da obrigação. Nota-se, ainda, que a incerteza sobre a validade de determinada prova não é exclusiva dos documentos eletrônicos, pois um suposto instrumento contratual impresso em papel, mesmo que assinado por qualquer das partes, também pode ter sua eficácia questionada pela parte contrária, permitindo, inclusive, a instauração de incidente de falsidade (BRASIL. STJ. REsp 1.381.603/MS. $4^{\mathrm{a}}$ T. Rel. Min. Luis Felipe Salomão, julg. 6.10.2016). 
tribunais brasileiros, o documento eletrônico tem encontrado ampla acolhida como fonte válida de prova, embora se verifique legítima preocupação a respeito da utilização e do valor da prova obtida no meio eletrônico. Na matéria, cumpre reservar atenção especial à tutela da dignidade humana no ambiente virtual, sendo vedada a prova ilícita. ${ }^{58}$

Já se decidiu, nessa direção, pela impossibilidade de "utilização de conversas retiradas de grupo fechado do Facebook em processo administrativo disciplinar", "por violação do direito fundamental à inviolabilidade das correspondências (artigo $5^{\circ}, \mathrm{XII}, \mathrm{CRF} / 88$ ), o qual inclui, por extensão, os grupos fechados do Facebook". ${ }^{59}$ Além da necessidade de se efetuar controle de merecimento de tutela das provas obtidas no meio eletrônico, outras questões surgem no que diz respeito à adequada avaliação, pelo magistrado, no caso concreto, do valor probante dos documentos eletrônicos, os quais, sendo lícitos, demandam ponderação quanto aos fatos que se destinam a provar.

A dinamicidade das relações travadas por meio da comunicação eletrônica exige do intérprete análise percuciente do suporte fático para que seja possível concluir, por exemplo, se o envio de e-mails sobre o conteúdo de certo contrato caracteriza a sua conclusão, vinculando as partes. No Tribunal de Justiça do Estado do Rio de Janeiro, examinou-se caso em que a parte autora, alegando a celebração de contrato de representação comercial com a ré - o que estaria comprovado por mensagens eletrônicas trocadas entre as partes -, postulava a execução do contrato, bem como a reparação por danos materiais e morais. $O$ TJRJ decidiu que a "troca de mensagens eletrônicas entre as partes, iniciadas pelo autor", configurariam "mera tratativa, de forma muito incipiente, e não celebração de contrato de representação", destacando que "o mero envio de modelo padrão de contrato de representação não endossa o início das atividades". ${ }^{60}$

Controvérsia semelhante - quanto à delimitação do momento de tratativas e da efetiva celebração de contrato por e-mail -, embora com suporte fático diverso, foi apreciada pelo TJDFT. No caso, a ré alegava que o contrato de fornecimento de cestas básicas e natalinas não teria se aperfeiçoado na data apontada pela parte autora, fato que se afigurava determinante para verificar se o "cancelamento" do contrato pela ré teria causado prejuízos à autora. O Tribunal, analisando diversos e-mails, concluiu que "o contrato foi firmado entre as partes em data anterior à descrita pelos recorrentes", de modo que a rescisão não teria sido razoável, sendo necessária a reparação dos prejuízos dela decorrentes. ${ }^{61}$

Como se sabe, o artigo $5^{\circ}$, LVI, da Constituição da República, prevê que "são inadmissíveis, no processo, as provas obtidas por meios ilícitos".

9 RIO DE JANEIRO. TJRJ. 3a C.C. Ap. Cív. 0382557-12.2013.8.19.0001. Rel. Des. Peterson Barroso Simão, jul. 25.06.2015. No caso, foram utilizadas mensagens eletrônicas provenientes de conversas pessoais de servidores públicos militares - em grupo ao qual somente eles tinham acesso - para instaurar sindicância. Segundo o Tribunal, um dos direitos constitucionais desrespeitados no caso foi "a inviolabilidade do sigilo da correspondência, o qual inclui pacificamente o e-mail e, por extensão, o grupo fechado de Facebook, eis que somente acessível o seu conteúdo pelos seus participantes, e não de forma irrestrita por qualquer pessoa que integre genericamente aquela rede social. O próprio Impetrado reconhece que se tratava de grupo fechado e que para acessá-lo era necessária a concordância do responsável pelo mesmo, não sendo seu acesso irrestrito a qualquer usuário do Facebook, afirmando, porém, que os agentes da Inteligência também eram Inspetores de Segurança e Administração Penitenciária e que, por isso, possuíam acesso a tal grupo. [...]. Assim sendo, obtenção do teor do conteúdo publicado no grupo fechado de Facebook por intermédio de agente infiltrado da Inteligência da Corporação, consubstancia-se em prova ilícita, eis que flagrantemente obtida por meio de violação direta a direito fundamental previsto no art. $5^{\circ}$, inciso XII, da CRFB/88. Vale ressaltar ser irrelevante o grau de dificuldade ou de tecnologia utilizado na obtenção das conversações em tela. Trata-se de diálogos privados e que jamais podem ser utilizados para instauração de processo administrativo disciplinar ou punições administrativas ao servidor".

60 RIO DE JANEIRO. TJRJ. 20ª C.C. Ap. Cív. 0301345-37.2011.8.19.0001. Rel. Des. Conceição Aparecida Mousnier Teixeira de Guimarães Pena, jul. 29.6.2016. Destaca a Desembargadora Relatora que, "ao contrário do afirmado pelo Autor, ora Apelante, foi ele quem procurou a Ré, por meio da correspondência eletrônica de fls. 358/359, datada de 5.11.2010, com o objetivo de informar seu interesse em atuar como representante na locação de máquinas de franquear digital (MFD) no Estado do Rio de Janeiro. A partir daí houve trocas de e-mails entre as partes, tendo a Ré enviado para o Autor, em 9.11.2010, um modelo de contrato de representação comercial, consignando que a documentação era para análise e avaliação do Autor, nos seguintes termos, in verbis: "Olá, Firmo, tudo bom? Seguem em anexo o Contrato de representação Comercial e a apresentação de canais. Peço que avalie e voltamos a nos falar". Outro caso interessante sobre o documento eletrônico como fonte de prova de aspectos essenciais ao contrato, também analisado no TJRJ, dizia respeito a celebração de promessa de cessão de direitos hereditários em que a cedente sustentava a ocorrência de lesão, em virtude de seu estado de vulnerabilidade decorrente do uso de medicamentos para depressão após a morte de seu pai. O TJRJ, analisando conjunto de correspondências eletrônicas entre as partes, concluiu pela existência de relação íntima entre as partes e plena capacidade mental da cedente ao tempo da celebração do negócio. Segundo o Tribunal, "as várias correspondências eletrônicas juntadas pela própria autora sugerem que entre as partes existiu forte relação de amizade e confiança, além de demonstrarem a plena capacidade mental da autora no período em que celebrado o negócio jurídico objeto desta demanda" (RIO DE JANEIRO. TJRJ. 16a C.C. Ap. Cív. 0191144-07.2013.8.19.0001. Rel. Des. Eduardo Gusmão Alves de Brito Neto, jul. 22.11.2016).

61 DISTRITO FEDERAL. TJDFT. 5a T.C. Ap. Cív. 0011679-03.2015.8.07.0001. Rel. Des. Josapha Francisco dos Santos, julg. 13.7.2016. Concluiu-se que, "diante da suspensão do contrato, ocorrida aos 28.11.2014 e de seu cancelamento, efetivado aos 9.12 .2014 pelas apelantes, data em que as cestas já estavam devidamente confeccionadas, tendo em vista o prazo fixado pelas partes para entrega (4.12.2014 a 11.12.2014), as recorrentes deverão arcar com os prejuízos advindos da tardia rescisão unilateral da avença". 
Aspecto igualmente complexo diz respeito ao documento eletrônico como fonte de prova da responsabilidade civil por dano moral decorrente do envio de mensagens ofensivas. Controverte-se, sobretudo, acerca da possibilidade de identificar, com segurança, o autor das mensagens, de modo a atribuir-lhe a responsabilidade. Ilustrativamente, em caso julgado pelo TJRS, negou-se a compensação por danos morais advindos do recebimento de e-mail ofensivo, ao argumento de que "um único e-mail, em que sequer resta certeza sobre seu remetente, não pode respaldar o pedido constante na inicial" ${ }^{6}$ Em outro caso, julgado pelo TJRJ, reformou-se sentença proferida em primeira instância para condenar a ré à compensação por danos morais causados ao autor em razão do recebimento de mensagens com conteúdo ofensivo enviadas do celular da ré ao celular do autor. O Tribunal rejeitou a alegação da ré de que não poderia ser responsabilizada porque havia perdido seu aparelho celular, do qual foram enviadas as mensagens ao tempo do envio. Afirmou-se, no voto condutor, que

restou comprovado que as mensagens foram de fato oriundas do celular da ré, sendo dela a responsabilidade sobre o aparelho, não importando a informação de que o 'perdeu'. Com efeito, no caso dos autos, observa-se que o dano moral restou devidamente configurado, uma vez que o autor acostou o documento [...] correspondente à tela de seu celular que contém a mensagem oriunda do celular da ré. ${ }^{63}$

Essa breve resenha já demonstra a complexidade das questões que atualmente se apresentam aos Tribunais brasileiros em matéria de documento eletrônico, a exigir, também da doutrina, a definição de critérios que auxiliem na construção da disciplina do documento eletrônico, garantindo maior segurança ao intérprete diante de novos suportes fáticos. O desafio se revela urgente, a julgar pela grande quantidade de casos julgados pelos Tribunais - que abrangem desde questões contratuais, como obrigações do locatário ${ }^{64}$ e resilição unilateral do contrato, ${ }^{65}$ até fatos jurídicos relevantes ao deslinde de controvérsias de direito de família ${ }^{66}$ - e pela consolidação, reconhecida pelo Superior Tribunal de Justiça, da prova eletrônica como fonte de prova admissível no ordenamento jurídico. ${ }^{67}$

\section{Conclusão}

As numerosas questões suscitadas confirmam as premissas inicialmente desenvolvidas, no sentido da imprescindibilidade do recurso ao ordenamento unitário, orientado pela axiologia constitucional, para o controle de merecimento de tutela da prova oriunda do meio eletrônico. O perigoso apego da subsunção, segundo parâmetros abstratos de incidência de um ou outro núcleo normativo, deve ser afastada, por revelar formalismo incompatível com a legalidade constitucional. Deve-se promover, em cada caso concreto, a construção da normativa aplicável, processo interpretativo que se realiza mediante o exame funcional das normas e a análise do suporte fático de incidência.

62 RIO GRANDE DO SUL. TJRS. 15ª C. C. Ap. Cív. 70032747990. Rel. Des. Otávio Augusto de Freitas Barcellos, jul. 25.11.2009. O caso chegou ao STJ, que, porém, negou recebimento ao recurso com base na Súmula n. 7: "Realmente, para se afastar a conclusão lançada no aresto impugnado de que 'um único e-mail, em que sequer resta certeza sobre seu remetente não pode respaldar o pedido constante na inicial' (e-STJ, fl. 317), é imprescindível o reexame de provas, tarefa inviável em sede de recurso especial, a teor da citada Súmula 7/STJ" (BRASIL. STJ. 4 ${ }^{\text {a T. }}$ AgRg no Ag 1.381.690/RS. Rel. Min. Raul Araújo, julg. 19.11.2015)

63 RIO DE JANEIRO. TJRJ. 16ª C.C., Ap. Cív. 0338013-36.2013.8.19.0001. Rel. Des. Lindolpho Morais Marinho, jul. 29.11.2016.

64 Em demanda relativa à reparação de danos ao imóvel após período delocação, o TJRJconsiderou que as mensagens eletrônicas trocadas entre locatário e locadora demonstrariam a boa-fé do locatário ao comunicar os problemas que causaram danos ao imóvel, bem como a "quitação da locadora acerca de eventual dano decorrente do banheiro" (RIO DE JANEIRO. TJRJ. 12a C.C. Ap. Cív. 0135378-32.2014.8.19.0001. Rel. Des. CherubinHelcias Schwartz Júnior, jul. 14.6.2016).

65 O TJDFT decidiu que "a parte pode rescindir contrato de prestação de serviços por meio de mensagem eletrônica (e-mail)". No caso, discutia-se se o envio de e-mail notificando a resilição unilateral do contrato produziria efetivamente a extinção da relação contratual. Conforme destacado pelo Tribunal, "o cerne da questão reside em definir se houve a rescisão unilateral do contrato pela apelante/ré, por meio de mensagem eletrônica (e-mail) enviada em 27 de setembro de 2011". Concluiu-se que "exigir que a parte que enviou o e-mail, contendo o pedido de rescisão de contrato, comprove que a empresa destinatária recebeu a referida mensagem eletrônica, mostra-se desarrazoado, imputando a uma das partes encargo excessivo" (DISTRITO FEDERAL. TJDFT. 5 T.C. Ap. Cív. 0032834-33.2013.8.07.0001 Rel. Des. Sebastião Coelho, julg. 5.11.2014).

66 No TJRJ, a análise de "cópias de conversas eletrônicas trocadas entre a recorrente e sua genitora" foi determinante para comprovar que a alimentanda, maior de idade, constituiu família, mantendo-se, desse modo, a decisão que exonerou a mãe da prestação de alimentos (RIO DE JANEIRO. TJRJ. 14a C.C. Ap. Cív. 0005605-63.2016.8.19.0000. Rel. Des. Gilberto Campista Guarino, jul. 3.8.2016).

67 BRASIL. STJ. 4 ${ }^{a}$ T. REsp 1.381.603/MS. Rel. Min. Luis Felipe Salomão, julg. 6.10.2016. 
O campo de avaliação e controle das provas, como visto, afigura-se de grande amplitude, sendo equivocada a perspectiva de redução das possibilidades probatórias em relação aos atos de forma livre por meio da chamada forma ad probationem. Também neste caso será necessário avaliar, conforme as circunstâncias fáticas e os valores prevalentes na situação regulada, se a previsão legal de "prova por escrito" impõe, mercê da confusão entre forma e prova do negócio jurídico, verdadeira forma ad substantiam ou se, ao reverso, não impede que o negócio seja provado por outras fontes, desde que lícitas.

O exame abrangente de licitude da prova não poderá, de qualquer forma, ignorar os avanços tecnológicos que caracterizam a contemporaneidade. Os denominados documentos eletrônicos adquirem protagonismo no cenário das provas, sendo necessário, portanto, reconhecer, na esteira do CPC, sua admissibilidade como fonte de prova e, sobretudo, desenvolver parâmetros que auxiliem o intérprete no controle de merecimento de tutela desses documentos, notadamente quanto à proteção da privacidade $\mathrm{e}$ à avaliação de autenticidade e valor probante.

\section{Referências}

ALVES, José Carlos Moreira. A parte geral do Projeto do Código Civil. Revista CEJ, América do Norte, v. 3, n. 9, 1999. Disponível em: <http://www.cjf.jus.br/ojs2/index.php/revcej/article/view/231/393>. Acesso em: 13 fev. 2017.

AZEVEDO, Antônio Junqueira de. Negócio jurídico: existência, validade e eficácia. São Paulo: Saraiva, 2002.

AZEVEDO, Antônio Junqueira de. Depósito de ouro e pedras preciosas feito em 1878. Forma e prova do contrato de depósito. Depósito mercantil e depósito bancário. Mora do credor. In: AZEVEDO, Antônio Junqueira de. Estudos e pareceres de direito privado. São Paulo: Saraiva, 2004. p. 249-262.

BEVILAQUA, Clovis. Teoria geral do direito civil. Rio de Janeiro: Francisco Alves, 1908.

BEVILAQUA, Clovis. Código Civil dos Estados Unidos do Brasil comentado. Rio de Janeiro: Francisco Alves, 1956. v. I.

BEVILAQUA, Clovis. Código Civil dos Estados Unidos do Brasil comentado. Rio de Janeiro: Francisco Alves, 1957. v. V.

CÂMARA, Alexandre Freitas. Das relações entre o Código Civil e o direito processual civil. In: DIDIER JR., Fredie; MAZZEI, Rodrigo (Coord.). Reflexos do novo Código Civil no direito processual. Salvador: JusPodivm, 2006. p. 109-124.

CINTRA, Antonio Carlos de Araújo; GRINOVER, Ada Pellegrini; DINAMARCO, Cândido Rangel. Teoria geral do processo. São Paulo: Malheiros, 2013.

DANTAS, San Tiago. Transcrições das aulas na Faculdade Nacional de Direito. [s.d.]. v. II.

DANTAS, San Tiago. Programa de direito civil. Rio de Janeiro: Forense, 2001.

DIDIER JR., Fredie. Regras processuais no novo Código Civil. São Paulo: Saraiva, 2004.

GAJARDONI, Fernando da Fonseca et al. Processo de conhecimento e cumprimento de sentença: comentários ao CPC de 2015. Rio de Janeiro: Forense, 2016.

GAMA, Guilherme Calmon Nogueira da. Prova do fato jurídico do Código Civil de 2002. In: DELGADO, Mário Luiz; ALVES, Jones Figueirêdo (Coord.). Questões controvertidas: parte geral do Código Civil. São Paulo: Método, 2007. p. 589-613.

GIANNICO, Maricí. A prova no Código Civil: natureza jurídica. São Paulo: Saraiva, 2005.

GOMES, Orlando. Introdução ao direito civil. Rio de Janeiro: Forense, 2016.

GONÇALVES, Carlos Roberto. Direito civil brasileiro. São Paulo: Saraiva, 2010. v.l. 
GRECO, Leonardo. A prova no processo civil: do Código de 1973 ao novo Código Civil. In: GRECO, Leonardo. Estudos de direito processual. Campos dos Goytacazes: Faculdade de Direito de Campos, 2005. p. 357-391.

JAYME, Erik. Identité culturelle et intégration: le droit internationale privé postmoderne. Recueil des Cours de l'Académie de Droit International de la Haye, La Haye, v. II, p. 9-267. 1955

LEWICKI, Bruno. Liberdade na prova das licenças de software. In: FRAZÃO, Ana; TEPEDINO, Gustavo (Coord.). O Superior Tribunal de Justiça e a reconstrução do direito privado. São Paulo: Revista dos Tribunais, 2011. p. 187-228.

LOPES, Miguel Maria de Serpa. Curso de direito civil. Rio de Janeiro: Freitas Bastos, 1989. v. I. LOPES, Miguel Maria de Serpa. Curso de direito civil. Rio de Janeiro: Freitas Bastos, 1993. v. IV. MARQUES, Claudia Lima. Diálogo das fontes. In: MARQUES, Claudia Lima; BENJAMIN, Antonio Herman V.; BESSA, Leonardo Roscoe. Manual de direito do consumidor. São Paulo: Revista dos Tribunais, 2016. p. 135-153.

MARTINS, Guilherme Magalhães. Formação dos contratos eletrônicos de consumo via internet. Rio de Janeiro: Forense, 2003.

MONTEIRO, Washington de Barros. Curso de direito civil - parte geral. São Paulo: Saraiva, 2007. v.l. MOREIRA ALVES, José Carlos. A parte geral do Projeto do Código Civil. Revista CEJ, Brasília, v. 3, n. 9, 1999. Disponível em: <http://www.cjf.jus.br/ojs2/index.php/revcej/article/view/231/393>. Acesso em: 13 fev. 2017.

MOREIRA, José Carlos Barbosa. Anotações sobre o título "Da prova" do novo Código Civil. Revista Trimestral de Direito Civil - RTDC, Rio de Janeiro, v. 6, n. 22, p. 97-113, abr./jun. 2005.

OLIVEIRA, Carlos Santos de. Da prova dos negócios jurídicos. In: TEPEDINO, Gustavo (Coord.). 0 Código Civil na perspectiva civil-constitucional: parte geral. Rio de Janeiro: Renovar, 2013. p. 499539.

PEREIRA, Caio Mário da Silva. Contratos e obrigações: pareceres. Rio de Janeiro: Forense, 2011. PEREIRA, Caio Mário da Silva. Instituições de direito civil. Rio de Janeiro: Forense, 2016a. v. I. PEREIRA, Caio Mário da Silva. Instituições de direito civil. Rio de Janeiro: Forense, 2016b. v. III. PERLINGIERI, Pietro. Forma dei negozi e formalismo degli interpreti. Collana: Pubblicazioni della Scuola di specializzazione in diritto civile dell'Università di Camerino, 51. Napoli: Edizioni Scientifiche Italiane, 1987.

PERLINGIERI, Pietro. Perfis de direito civil: introdução ao direito civil constitucional. Rio de Janeiro: Renovar, 2002.

PERLINGIERI, Pietro. Complessità e unitarietà dell'ordinamento giuridico vigente. Rassegna di diritto civile, Napoli: Edizioni Scientifiche Italiane, v. 26, n. 1, p. 188-214, 2005.

PERLINGIERI, Pietro. O direito civil na legalidade constitucional. Rio de Janeiro: Renovar, 2009.

PONTES DE MIRANDA, Francisco Cavalcanti. Tratado de Direito Privado. São Paulo: Revista dos Tribunais, 2012. t. III.

REGO, Hermenegildo de Souza. Natureza das normas sobre prova. São Paulo: Revista dos Tribunais, 1985.

RODRIGUES, Silvio. Direito civil. São Paulo: Saraiva, 2003. v. I.

SANTOS, J. M. de Carvalho. Código Civil brasileiro interpretado. Rio de Janeiro: Freitas Bastos, 1963. v. III.

SANTOS, J. M. de Carvalho. Código Civil brasileiro interpretado. Rio de Janeiro: Freitas Bastos, 1961. v. XVIII. 
SCHREIBER, Anderson. Contratos eletrônicos e consumo. Revista Brasileira de Direito Civil RBDCivil, Rio de Janeiro, v. I, n. 1, p. 88-110, 2014. Disponível em: <https://www.ibdcivil.org.br/image/ data/revista/volume1/rbdcivil-volume-1-doutrina_004.pdf>. Acesso em: 13 fev. 2017.

TARTUCE, Fernanda. Meios de prova no Código de Processo Civil e no Código Civil. In: TARTUCE, Flávio; CASTILHO, Ricardo (Coord.). Direito patrimonial e direito existencial: estudo em homenagem à Professora Giselda Maria Fernandes Novaes Hironaka. São Paulo: Método, 2006. p. 163-176.

TARTUCE, Flávio. O tratamento das provas no Código Civil e o impacto do novo CPC. In: O novo CPC e o direito civil: impactos, diálogos e interações. São Paulo: Método, 2015. p. 171-223.

TEPEDINO, Gustavo. A disciplina civil-constitucional das relações familiares. In: Temas de direito civil. Rio de Janeiro: Renovar, 2008. p. 419-443.

TEPEDINO, Gustavo; BARBOZA, Heloisa Helena; MORAES, Maria Celina Bodin de. Código Civil interpretado conforme a Constituição da República. Rio de Janeiro: Renovar, 2012. v. II.

TEPEDINO, Gustavo. Esboço de uma classificação funcional dos atos jurídicos. Revista Brasileira de Direito Civil - RBDCivil, Rio de Janeiro, v. I, n. 1, p. 8-37, 2014. Disponível em: <https://www.ibdcivil.org. br/image/data/revista/volume1/rbdcivil-volume-1-doutrina_001.pdf>. Acesso em: 13 fev. 2017.

TEPEDINO, Gustavo. Diálogos entre fontes normativas na complexidade do ordenamento. Editorial.

Revista Brasileira de Direito Civil - RBDCivil, Rio de Janeiro, v. 5, n. 2, p. 6-9, jul./set. 2015. Disponível em: <https://www.ibdcivil.org.br/image/data/revista/volume5/rbdcivil-volume-5_gustavo-tepedino_pg6-9. pdf>. Acesso em: 13 fev. 2017.

TEPEDINO, Gustavo. O papel atual da doutrina do direito civil entre o sujeito e a pessoa. In: TEPEDINO, Gustavo et al. (Coord.). O direito civil entre o sujeito e a pessoa: estudos em homenagem ao Professor Stefano Rodotà. Belo Horizonte: Fórum, 2016. p. 17-38.

THEODORO JÚNIOR, Humberto. Comentários ao novo Código Civil. Rio de Janeiro: Forense, 2008. V. III. t. II.

VENOSA, Sílvio de Salvo. Direito civil. São Paulo: Atlas, 2005. v. 1.

VILLELA, João Baptista. Do fato ao negócio: em busca da precisão conceitual. In: AZEVEDO, Antonio Junqueira de (et al.). (Org.). Estudos em homenagem ao professor Washington de Barros Monteiro. São Paulo, Saraiva, 1982. p. 255-266.

WALD, Arnoldo. Direito civil: introdução e parte geral. São Paulo: Saraiva, 2009.

Recebido em: 21/03/2017.

Aprovado em: 30/05/2017. 